\title{
"CATCHING THE SIGN": \\ Catalogue Rhetoric in "The Sleepers"
}

James Perrin Warren

In THE MANUSCRIPT Primer of Words, Walt Whitman defines the "Real Grammar" as "that which declares itself a nucleus of the spirit of the laws, with liberty to all to carry out the spirit of the laws, even by violating them, if necessary." The difficulty in Whitman's definition is that it sets up a conflict between laws and the violation of laws, between a linguistic framework of rules and an individual artist's violation of the framework for his own expressive purposes. In previous essays I have tried to show how this inevitable conflict figures in the diction and syntax of "Song of Myself," where the "liberty" of the spirit establishes an essentially irresolvable but poetically fruitful opposition between the conceptual and grammatical poles of action and being. ${ }^{2}$

The temporally dynamic aspects of Whitman's poetics become clear in the poet's use of catalogues in the 1855 poem "The Sleepers." Here the catalogue is a key element both in the poem's structure and in Whitman's selfrepresentation. Howard J. Waskow has pointed out that "The Sleepers" is a companion piece to "Song of Myself," for in both poems the speaker is involved in performing an action. ${ }^{3}$ The twin relationship between the poems is apparent in the first line of "The Sleepers": "I wander all night in my vision" echoes Section 33 of "Song of Myself," where the poet asserts, "I am afoot with my vision." 4 Because of this initial echo, we might expect "The Sleepers" to use the same catalogue technique for the same effects created in "Song of Myself." 5 But the speaker of "The Sleepers" is not simply energizing himself through the rhetorical act of speaking, an act that constitutes a poetic self. In the first lines of "Song of Myself," the speaker is a "loafer"; in the beginning of "The Sleepers," he is already moving:

\footnotetext{
I wander all night in my vision,

Stepping with light feet, swiftly and noiselessly stepping and stopping,

Bending with open eyes over the shut eyes of sleepers,

Wandering and confused, lost to myself, ill-assorted, contradictory,

Pausing, gazing, bending, and stopping. (1-5)
}

The first stanza of the poem establishes a rhythmical frame based upon coordination and syntactic parallelism. The clause "I wander all night in my vision" sets the frame for the series of phrasal parallels. These participial phrases form a paratactic sequence modifying both the speaker and the speaker's action, and the framing effect of the initial clause is strengthened by the anaphora of the modifying participles: "Stepping," "Bending," "Wander- 
ing," and "Pausing" function as the primary repetends, and "Wandering" is particularly important because it repeats the verb of the clausal frame.

This description of the syntactic rhythm of the first stanza emphasizes the order of Whitman's free verse. But it is equally important to stress the effects of disorder created by the rhythm of syntactic parallelism. On the most basic semantic level, the words themselves emphasize movement and action, but they also denote movement without direction. A major concern for the poet in this lyric of crisis is to find a personal center for the "wandering" self. But the parallelisms which frame the poet's concern also provide the possibility of escape from the frame. Thus, for instance, the last two lines of the stanza shift from the repetition of dynamic verbal forms to a seemingly chaotic whirl of stative forms. The repetition of the image of "wandering" gives way to "confused, lost to myself, ill-assorted, contradictory" (4). By shifting from present participial forms to past participial forms, Whitman moves from the representation of an active self to the representation of a passive self. The passage becomes quite literally "contradictory," in the sense that it seems to speak against itself. But this "ill-assorted" use of parallelism accords perfectly with the performative quality of Whitman's poetics, for the syntax mimes the representation of an "ill-assorted" self.

The last line of the stanza brings us back to the present participle and to action, but the actions represented are hesitant. There is no celebration in the acts of "Pausing, gazing, bending, and stopping." Indeed, the tentative quality of the actions undermines the poet's return to the dynamic verbal form. This is especially true of the last term in the series. The terminal repetition of "stopping" $(2,5)$ contradicts the anaphoric repetition of dynamic present participles. Unlike the final line of "Song of Myself," which it clearly echoes, the act of "stopping" threatens to block the performing of the speech-act. At the threshold of "The Sleepers," then, the poet stops, and the effect of this pause is to raise doubts about the poet's ability to "loose the stop from your throat" ("Song of Myself," 84).

Whitman solves the problem he sets himself in the first stanza by constructing a transcendental self out of the act of "wandering." That is, he forges a poetic identity by going through the action of identifying with the sleepers in the poem. The answer to the problem of poetic identity thus revolves about the relationship of the many to the one, the world of persons and objects to the poet.

This problematic premise for the poem is evident in a prose manuscript notebook which is the basis for "The Sleepers." 0 On the first leaf of the notebook, Whitman considers the future realization of the soul, and he does so in terms that recall his pronouncements upon the "Real Grammar":

No doubt the efflux of the soul comes through beautiful gates of laws that at some future period perhaps a few score millions of years, we may understand better. - At present, its tide is what folks call capricious, and cannot well be traced. Why as I look in the railroad car at some half 
turned face, do I love that woman? Though she is neither young nor fair complexioned?-She remains in my memory afterward for a year, and I calm myself to sleep at night by thinking of her. ${ }^{7}$

This passage begins with a meditation of the "vista" of spiritual evolution, but it quickly moves to the mysterious affection Whitman feels for an unknown woman and, from there, to his memory of the woman and the calming influence of his memory: "I calm myself to sleep at night by thinking of her." The "efflux of the soul" remains a mystery, a divine tendency reminiscent of Emerson's meditation in "Experience," but it is somehow connected to the poet's unspoken love for other persons. ${ }^{8}$

A second manuscript passage clarifies this vague connection. On the fifth leaf of the "Sleepers" notebook, Whitman returns to the relationship of the many to the one:

While the curtain is down at the opera, while I swim in the bath, while I wait for my friend at the corner, while I behold and am beheld by people; I speak little or nothing; I make no gifts to them: I do not turn as much as my neck or pat my instep... we never met before-never heard or shall hear names nor dates nor employments. - With all this, some god walks in noiseless and resistless, and takes their hearts out of their breasts, and gives them to me for ever. - Often I catch the sign; and oftener, no doubt, it flies by me as unknown as my neighbor's dreams. $(D B N, 3: 765-66)$

"Some god walks in noiseless and resistless." The "god" figures the transcendental or poetic self, and the figure mediates between the poet and the numberless other, between the one and the many. But the presence of the god may fly by the poet, as "unknown as my neighbor's dreams." So the poem "The Sleepers" would seem to be Whitman's attempt to "catch the sign" of the "god," both in himself and in other sleepers.

Whitman's strategy for catching the sign involves, first and foremost, the act of identifying with the other sleepers. Thus the next five stanzas of the poem move away from the "ill-assorted" speaker to the vision of the many. And this movement coordinates with the further development of the rhythmical frame. The five stanzas consist of two, three, and four lines, and the number of lines creates a dream-like, tentative effect, in much the same way that the three-line and two-line stanzas of Section 11 of "Song of Myself" mark the transition from the rowdy, good-natured "loafer" to the hesitant observer of the "twenty-eight young men."

The first of the five stanzas is the shortest: "How solemn they look there, stretch'd and still, / How quiet they breathe, the little children in their cradles" (6-7). The rhythmical frame is set by the paired clauses and the anaphoric repetition of "How." The stanza creates a tone of hushed exclamation because the frame is not developed any further. The tone is signally appropriate to the situation presented in the first stanza of the poem, and it has its origins in the following passage from the "Sleepers" notebook: 
Has what I have said . . . seized upon you[r] soul and set its sign there If not then I know there is no elementary vigor in my words If not, then I throw my words among the other parings and crusts of the swill tub, and go home and bathe myself, and listen to music, and touch my lips to the flesh of sleeping children, an come and try again. $(D B N, 3: 769)$

The manuscript passage recounts the same drama of doubt that informs the first stanza of the poem, and the drama is resolved in both cases - at least temporarily-by the image of sleeping children.

The poet's search for the "elementary vigor in ... words" continues in the next four stanzas of "The Sleepers." The clausal frame set by the second stanza of the poem gives way to a mixed stanza:

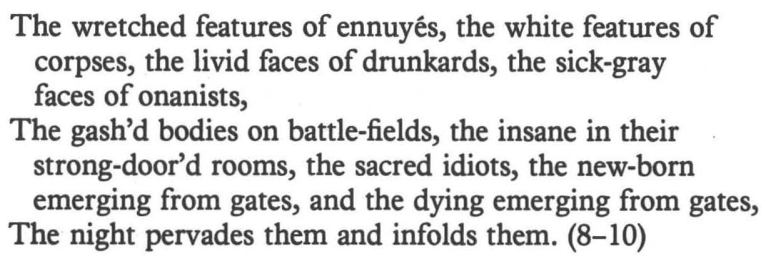

The first two lines of the stanza represent the poet's first attempt to expand into a catalogue, and the nine phrases progress from the "wretched" and "livid" faces to the "sacred idiots" and the "emerging from gates" of both the newly born and the newly dead. The image of "gates" recalls the first leaf of the "Sleepers" notebook, where Whitman asserts that "the efflux of the soul comes through beautiful gates of laws" ( $D B N, 3: 764)$. Moreover, the phrasal catalogue enacts that spiritual efflux, for the progression in the catalogue remains half-hidden and "cannot well be traced" $(D B N, 3: 764)$. The movement from the phrasal catalogue to the clause controlling the phrases parallels the movement from the many to the one, from disunity to unity. Whitman seals both the effect and the stanza with the closing line: "The night pervades them and infolds them."

The next three stanzas maintain the steady tone of affirmation through the regularity of form and rhythm. All three contain four lines, and all three employ the repetition of the "X sleeps" syntactic formula. The twelve lines could form an effective clausal catalogue of the type Whitman creates in Section 15 of "Song of Myself," but in "The Sleepers" the poet emphasizes the separate character of the sleepers by grouping them in separate stanzas. ${ }^{9}$ Thus the first of the three stanzas presents images of family, the second images of loss and evil, and the third images of frustrated desires. The movement in the three stanzas returns to the confusion and chaos of the earlier phrasal catalogue, but this apparent regression masks the "efflux of the soul," which, Whitman notes, "folks call capricious" ( $D B N, 3: 764)$.

The process of identification again becomes important in the rest of Section 1 of the poem. The poet returns to himself as a figure of the separate observer: 
I stand in the dark with drooping eyes by the worstsuffering and the most restless,

I pass my hands soothingly to and fro a few inches from them,

The restless sink in their beds, they fitfully sleep. (23-25)

Even though the observer passes his hands a few inches from the sleepers, he remains separate from any physical contact with them. As in the passage from the "Sleepers" notebook, "some god" must "walk in noiseless and resistless" to close the gap between the many and the one.

Whitman's need for a transcendental self to mediate between the many and the one clearly emerges in the next two stanzas:

Now I pierce the darkness, new beings appear,

The earth recedes from me into the night,

I saw that it was beautiful, and I see that what is not the earth is beautiful.

I go from bedside to bedside, I sleep close with the other sleepers each in turn,

I dream in my dream all the dreams of the other dreamers,

And I become the other dreamers. (26-31)

The first line in this passage is an addition made in the 1860 edition of Leaves of Grass, and it adumbrates the poet's movement away from the physical beings of the earth. In receding, the earth becomes a part of the past ("I saw that it was beautiful"), and the poet can now perceive "new beings" in "what is not the earth." This allows the poet to return to the sleepers in order to place himself in a new relation with them. He dreams the one dream which includes the many dreams of the dreamers, and in so doing he asserts that he "become[s] the other dreamers;" The act of observation gives way to the act of identification.

By enacting the identification of the poetic self with the sleepers, Whitman gains verbal power over the problem he addresses in the poem. It is hardly surprising, then, that the ensuing stanzas celebrate the active role of the poet in perceiving the beautiful "efflux of the soul" where it is least apparent:

I am a dance-play up there! the fit is whirling me fast!

I am the ever-laughing-it is new moon and twilight,

I see the hiding of douceurs, I see nimble ghosts whichever way I look,

Cache and cache again deep in the ground and sea, and where it is neither ground nor sea. 
Well do they do their jobs those journeymen divine,

Only from me can they hide nothing, and would not if they could,

I reckon I am their boss and they make me a pet besides,

And surround me and lead me and run ahead when I walk,

To lift their cunning covers to signify me with stretch'd arms, and resume the way;

Onward we move, a gay gang of blackguards! with mirth-

shouting music and wild-flapping pennants of joy! (32-41)

Whitman's manuscript notebook for "The Sleepers" reveals that he worked on several versions of these lines. The second leaf of the notebook contains the phrase "pennants of joy" $(D B N, 3: 765)$, but in that passage the phallic image conveys a sense of frustration or impotence, where the "pennants ... sink flat and lank in the deadest calm."10 On the seventh and eighth leaves, Whitman changes the tone to commendation and power. The passage is headed "The Poet," and Whitman celebrates the penetrating sight which can perceive beauty where "ten million supple-fingered gods are perpetually employed hiding beauty in the world-burying it everywhere in everythingand most of all spots that men and women do not think of, and never look-as in death" $(D B N, 3: 766)$. The final leaf of the notebook presents the most thorough development of the passage, and most of the wording of the two stanzas is worked out completely $(D B N, 3: 770)$.

The salient point in the manuscript trials is the image of the "supplefingered gods" who hide beauty in "Death and Poverty and Wickedness" (3:770). In the poem, these gods become "nimble ghosts" (34), and in both the manuscript and the poem they are referred to as the "journeymen divine." The poem assumes the same power as the "nimble ghosts" by hiding the theme it develops. Whitman excludes all mention of hidden beauty, and the previous stanzas of the poem allow him to omit the blatant reference to death, poverty, and wickedness. But because we now know that the "Sleepers" notebook contains Whitman's meditations on the "god [who] walks in noiseless and resistless," we can understand that the poet becomes the "boss" and "pet" of the seemingly capricious "efflux of the soul." In this context, moreover, the play on the word "journeymen" becomes clear, for it mingles the image of democratic workingmen with the image of a spiritual journey.

The image of spiritual progress continues in the final movement of the first section. And the "Sleepers" notebook once again renders valuable service. The extended seduction scene that closes Section 1 creates the same dream-like tone which characterizes Section 11 of "Song of Myself." In both sections, the poet assumes the role of a female, and in both the physical act of sex is displaced by the metaphysical act of identification. In "The Sleepers," the connection between the seduction scene and the foregoing account of the "journeymen divine" is far from clear. But in the manuscript notebook, Whitman makes the connection for us: 
I reckon he is boss of those gods; and the work they do is done for him, and all that they have concealed for his sake-Him they attend outdoors or indoors. . . They run ahead when he walks, and lift their cunning covers, and signify him with pointed stretched arms. - (They undress and bring her naked to his bed, that they may sleep together; and she shall come again whenever he will, and the taste shall be sweeter and sweeter always) ${ }^{11}$

The figure of the naked female is clearly the gift of the gods to their "Boss," the poet. Whitman complicates the figure in the poem by assuming the role of the female and by enacting a seduction of the female by the darkness instead of by a lover. These alterations of the figure obscure its function, but it is nonetheless certain that the figure of the naked female parallels the "journeymen divine," who "lift their cunning covers" for the poet. The double displacement also becomes apparent, for the seduction is spiritual instead of physical.

Whitman develops the spiritual nature of the scene and the connection with the "supple-fingered gods" in the last two stanzas of the section:

My hands are spread forth, I pass them in all directions,

I would sound up the shadowy shore to which you are journeying.

Be careful darkness! already what was it touch'd me?

I thought my lover had gone, else darkness and he are one,

I hear the heart-beat, I follow, I fade away. (55-59)

The image of darkness as "journeying" recalls, of course, the "journeymen divine," and the "shadowy shore" surely signifies death. The last stanza partially undercuts these images of spiritual evolution, for it represents the physical lover and the darkness as a unity. Whitman closes the section with the sound of the heartbeat and the fading of the dream, which is also the fading of the poet's voice and the fading of the female's identity. This is to say that the moment of spiritual oneness, the joining of the many and the one, is only momentary, for it only takes place in the poet's act of identification. And that act, however spiritual, remains bound to the world of time and change.

The temporal aspect of Whitman's concern with the "efflux of the soul" figures prominently in the setting of the rhythmical frame. The first section of the poem features short stanzas and coordinate clauses, and these formal elements combine to represent an active, searching poetic self, a transcendental spirit that forms itself through the act of identifying with the many sleepers it encounters on its journey through the night. Moreover, this paradoxical crossing between the many and the one can never be completed. The perpetual action of the god who "walks in noiseless and resistless" must be repeated again and again, over and over, for the action both removes the poet from the world of time and returns him to that world.

In Sections 2-6 of the poem, Whitman develops both the rhythmical frame and the paradoxical relationship of the poetic self to the world of time. The poet maintains his active search for the dreams of the many sleepers, and 
he enacts identification as a means toward identity. The dreams Whitman presents in these sections of the poem feature loss, physical danger, and death, and these themes accord well with the overarching concern with the "efflux of the soul." So, for example, in Section 2 the poet becomes the old grandmother (62-63), the sleepless widow (64-65), and the shroud (66-67).

In Section 3 Whitman develops the nightmarish vision of the "beautiful gigantic swimmer" (70-80). The swimmer recalls the poet's own pleasure in bathing, as well as the "twenty-ninth bather" of "Song of Myself." The passage in the poem also supports this identification between the poet and the swimmer, for Whitman notes that the "courageous giant" is "in the prime of his middle age" (75). This recalls the image of the poet presented in the final version of "Song of Myself": "I, now thirty-seven years old in perfect health begin, / Hoping to cease not till death" (8-9). Whitman added these lines to the 1881 edition of the poem, so it is obvious that he idealized his earlier physical and poetic health. ${ }^{12}$

Despite this measure of identification, the representation of the poetic self in Section 3 emphasizes a certain degree of separation. In Section 2, the poet becomes the various people or objects he sees, but here he remains caught in the act of seeing. This degree of separation leads to the crisis of Section 4, a crisis which echoes the opening stanza of the poem. Separation from the many leads to a meditation on the poet's one self, and this meditation echoes the helplessness of the drowning swimmer in Section 3:

I turn but do not extricate myself,

Confused, a past-reading, another, but with darkness yet.

The beach is cut by the razory ice-wind, the wreck-guns sound,

The tempest lulls, the moon comes floundering through the drifts.

I look where the ship helplessly heads end on, I hear the burst as she strikes, I hear the howls of dismay, they grow fainter and fainter.

I cannot aid with my wringing fingers,

I can but rush to the surf and let it drench me and freeze upon me.

I search with the crowd, not one of the company is wash'd to us alive,

In the morning I help pick up the dead and lay them in rows in a barn. (81-89)

The first stanza clearly echoes the opening stanza of the poem. The poet returns to his original "confused" state, a situation from which he is unable to extricate himself. The compound "past-reading" parallels the idea Whitman hits upon in the "Sleepers" notebook: "She remains in my memory afterward for a year" $(D B N, 3: 764)$. Further, it recalls the receding earth in Section 1 of 
"The Sleepers," an image that allowed the poet to extricate himself from the confused relationship of the many and the one. Here, however, the act of "past-reading" does not appear to have freed the poet; instead, the "new moon" of Section 1(33) now "comes floundering through the drifts" (84). The immediacy of both Section 3 and Section 4 appears to work against the poet, as if the act of identifying with the dreams of the many dreamers threatened to destroy the barely created poetic self.

In Sections 5 and 6, Whitman extricates himself from the confusion of dark dreams by pushing the dreams into the past and by creating a temporal frame for his transformations of identity. The initial word of Section 5, "Now," signals a series of "past-readings" which the poet presents in the form of memories. Section 5 delivers two scenes with General Washington, where defeat and farewell disguise the founding of the new republic. Section 6 begins with the repetition of the "Now" that signals both a present performance and a pushing of the performing act into the past: "Now what my mother told me one day as we sat at dinner together" $(100)$. The phrase "one day," which is a revision of 1881, replaces the more immediate phrase "today," and the revision places the performance of telling the story of the "red squaw" at a further remove from the present.

In the first five editions of Leaves of Grass, Whitman moves from his mother's dinnertime memory of the red squaw to the evocation of a black slave:

Now Lucifer was not dead . . . . or if he was I am his sorrowful terrible heir;

I have been wronged . . . . I am oppressed . . . . I hate him that oppresses me,

I will either destroy him, or he shall release me.

Damn him! how he does defile me,

How he informs against my brother and sister and takes pay for their blood,

How he laughs when I look down the bend after the steamboat that carries away my woman.

Now the vast dusk bulk that is the whale's bulk ... : it seems mine,

Warily, sportsman! though I lie so sleepy and sluggish, my tap is death. (116[1]-[8]) ${ }^{13}$

The repetend "Now" once again signals the play between the past and the present, as does the mixture of past and present tenses in the first line of the passage. The figure of the slave who has lost his woman parallels the figures of isolation and loss in the previous "past-readings." Still, the 1881 deletion of these lines has its rationale. The two "past-readings" of Sections 5 and 6 play upon the distinction between public and private loss, and the figure of "Lucifer's sorrowful terrible heir" seems historical and topical. Moreover, 
the figures in the two sections are not only figures of loss, for in both the public and the private scenes joy mingles with sorrow. This mixture is undercut by the figure of the slave, so Whitman's revision adds coherence to the movement of the poem, which carries us toward the "efflux of the soul" the poet seeks.

The efflux comes, finally, in Sections 7 and 8 of "The Sleepers," and it is figured by the poet's use of catalogues. Through the first six sections of the poem Whitman rarely extends a series of syntactic parallelisms beyond three lines, and when he does (11-22) he breaks the catalogue into stanzas of no more than four lines. This formal feature, we have seen, parallels the poet's dream-like, hesitant performance of identification. The movement between the many and the one corresponds to the movement between the past and the present, but these twin movements must be repeated in a never-ending dialectic from which the poet cannot disentangle himself. In the last two sections of the poem, Whitman brings together his many transformations, and he does so by framing the many acts within temporal catalogues. The catalogues represent the final expansion by the poet, the ultimate "efflux of the soul."

Section 7 effectively announces this final expansion by shifting the imagery from darkness to "A show of the summer softness - a contact of something unseen - an amour of the light and air" (117). The "something unseen" recalls the "hiding of douceurs" and the work of the "journeymen divine" developed in Section 1. In the next stanza of Section 7, the poet joins the new imagery of light and love with both himself and the many sleepers: "O love and summer, you are in the dreams and in me" (120). The imagery of changing seasons and plentiful harvests further develops the poet's tone of affirmation and provides the transition to the first of four catalogues.

The first catalogue is exclusively clausal, and it presents the dynamic return of the many, who are no longer confined to the role of sleepers:

Elements merge in the night, ships make tacks in the dreams,

The sailor sails, the exile returns home,

The fugitive returns unharm'd, the immigrant is back beyond months and years,

The poor Irishman lives in the simple house of his childhood with the well-known neighbors and faces,

They warmly welcome him, he is barefoot again, he forgets he is well off,

The Dutchman voyages home, and the Scotchman and Welshman voyage home, and the native of the Mediterranean voyages home,

To every port of England, France, Spain, enter well-fill'd ships,

The Swiss foots it toward his hills, the Prussian goes his way, the Hungarian his way, and the Pole his way,

The Swede returns, and the Dane and Norwegian return. (123-131) 
The image of the "well-fill'd ships" echoes the "barns . . . well-fill'd" in the previous stanza, and it effectively reverses the nightmarish vision of the shipwreck in Section 4. The catalogue concentrates upon the return of the many to their respective homelands, and that return is represented as an on-going activity through the use of dynamic verbs. The clausal character of the passage insists upon this dynamic image, and Whitman further emphasizes the progressivist quality of the return by stating that "the immigrant is back beyond months and years" (125). This is a curious turn of phrase, for we expect to read "after months and years." The word "beyond" suggests, then, that the return is taking place at some infinitely distant time in the future, even though Whitman's catalogue enacts the arrival in the present. In this sense of future deferral, the phrase recalls the image of the poet and "journeymen divine" in Section 1: "Onward we move, a gay gang of blackguards" (41). The assertion of arrival or return results in the incantatory performance of the act of arriving or returning.

The dynamic nature of the first clausal catalogue gives way immediately to a catalogue based on phrases:

The homeward bound and the outward bound,

The beautiful lost swimmer, the ennuyé, the onanist, the female that loves unrequited, the money-maker,

The actor and the actress, those through with their parts and those waiting to commence,

The affectionate boy, the husband and wife, the voter, the nominee that is chosen and the nominee that has fail'd,

The great already known and the great any time after to-day,

The stammerer, the sick, the perfect-form'd, the homely,

The criminal that stood in the box, the judge that sat and sentenced him, the fluent lawyers, the jury, the audience,

The laugher and weeper, the dancer, the midnight widow, the red squaw,

The consumptive, the erysipalite, the idiot, he that is wrong'd, The antipodes, and every one between this and them in the dark, I swear they are averaged now-one is no better than the other, The night and sleep have liken'd them and restored them. (132-143)

The phrases at first appear to summarize the earlier images of the sleepers, but it is clear that the poet both develops certain images more fully than before and adds new images. For instance, the earlier images of the murderer and prisoner (16-17) are given full play (138), while the image of "the homely" recalls most closely the unused passage from the "Sleepers" notebook: "She is neither young nor fair complexioned" $(D B N, 3: 764)$.

The phrases in the catalogue tend to create a stative effect, even though the random ordering of the phrases and the addition of new images cause the language of the passage to act in more dynamic ways than we might expect from a simple summary. Whitman furthers this tentative effect by reducing 
the welter of images to "the antipodes." He then provides a temporal frame for the many by ending the catalogue with three clauses: "I swear they are averaged now-one is no better than the other, / The night and sleep have liken'd them and restored them" (142-143).

The key word "now" parallels the poet's earlier use of the word in Sections 5 and 6. It asserts, moreover, that the many are being "averaged" at this present moment, in the act of the poet's saying or writing. In summarizing his "past-readings," therefore, Whitman transforms the act of "past-reading" into the act of "present-saying." Moreover, he enables himself to affirm a positive vision of the relationship between apparent evil and eventual good, and this affirmation, in the simple "I swear," is the first real assertion of the poet's belief in the "elementary vigor in [his] words" ( $D B N, 3: 769)$.

The poet enacts the "elementary vigor" in the four stanzas which close Section 7. The hidden themes of beauty and the soul become explicit here, and this adumbration of the themes shows just how central to the poem the "Sleepers" notebook must be:

\author{
I swear they are all beautiful, \\ Every one that sleeps is beautiful, every thing in the \\ dim light is beautiful, \\ The wildest and bloodiest is over, and all is peace. \\ Peace is always beautiful, \\ The myth of heaven indicates peace and light. \\ The myth of heaven indicates the soul, \\ The soul is always beautiful, it appears more or it \\ appears less, it comes or it lags behind, \\ It comes from its embower'd garden and looks pleasantly \\ on itself and encloses the world, \\ Perfect and clean the genitals previously jetting, and \\ perfect and clean the womb cohering, \\ The head well-grown proportion'd and plumb, and the \\ bowels and joints proportion'd and plumb. (144-153)
}

The first two stanzas create a stative effect through the use of the stative verb "to be." And this grammatical effect accords with the poet's act of swearing that "peace and night" are now the result of all the dynamic scenes of suffering and loss he has presented as his own. The stative quality of the lines continues in the first part of the third stanza. "The myth of heaven indicates the soul, / The soul is always beautiful" (149-50) forms a rhetorical chiasmus with the previous stanza ("Peace is always beautiful, / The myth of heaven indicates peace and night."), and the chiasmus establishes a complex homology of equivalences through syntactic parallelism. The homology breaks down to this basic idea: the soul is peace (and night), and the myth of heaven points toward these equivalent terms. 
The rest of the third stanza does not remain stative in its grammar or in its effects. After the poet asserts that "The soul is always beautiful," he moves into a presentation of the soul's activities. The soul "appears," "comes," "lags behind," "comes," "looks," and "encloses." These dynamic verbs create the effect of activity and process, so that the image of the stable, permanently beautiful soul gives way to the image of the dynamic, perpetually active soul. Once again, however, Whitman mixes stative and dynamic forms, creating a balance between them: the dynamic clauses frame the last two lines of the stanza, where phrases conclude with the mixture of dynamic syntax ("Jetting" and "cohering") and stative syntax ("The head well-grown proportion'd and plumb, and the bowels and joints proportion'd and plumb").

The three stanzas move toward the slight expansion of the five-line third stanza, but they function as a transition for the third of Whitman's four catalogues, a seven-line stanza to close the section. The counterpointing of stative and dynamic syntax enacts the dialectic of past and present, identity and activity.

The soul is always beautiful,

The universe is duly in order, every thing is in its place,

What has arrived is in its place and what waits shall be

in its place,

The twisted skull waits, the watery or rotten blood waits,

The child of the glutton or venerealee waits long, and the child of the drunkard waits long, and the drunkard

himself waits long,

The sleepers that lived and died wait, the far advanced are to go on in their turns, and the far behind are to come on in their turns,

The diverse shall be no less diverse, but they shall flow and unite-they unite now. (154-160)

The catalogue begins with three stative lines featuring the verb "to be" and simple predication. But the lines do not remain simply "in . . place." In order to give a true idea of the "efflux of the soul," the poet must emphasize the fact that the realization of the soul may take place "at some future period perhaps a few score millions of years" $(D B N, 3: 764)$. Thus the syntactic repetend becomes "waits," then "waits long."

The movement from "past-reading" to "present-saying" appears in the last two lines of the catalogue: the poet attempts to balance the "far advanced" and the "far behind" by presenting the "efflux of the soul" as it "comes through beautiful gates of laws" $(D B N, 3: 764)$. So the paired verb phrases combine the stative and the dynamic: "are to go on in their turns" and "are to come on in their turns" present future possibility as present law. The act of asserting leads the poet to his most extravagant performance of "presentsaying": "The diverse shall be no less diverse, but they shall flow and unite-they unite now." Again the future "efflux of the soul" is figured as tak- 
ing place in the present of the poem, in the act of saying or writing. Whitman's assertion "they unite now" climaxes the series of temporal transformations, the "past-readings" he has performed. Most importantly, the poet manages the assertion by placing his many identifications and the identities of the many sleepers within the temporally flowing frame of spiritual progress. Only by deferring the "efflux of the soul" to an infinitely distant future can the poet earn the possibility of asserting that the flowing outward is taking place in the present.

This paradoxical relationship between two orders of time and two aspects of Whitman's poetics is one reason why the poem does not end with the simple assertion of unity within variety. The final lines of Section $7 \mathrm{mix}$ stative and dynamic forms, future realization and present action, the one and the many, but the mixture is never a perfect one. Thus the poet must continue his expansions beyond the temporal and rhythmical frames he sets himself, for the "efflux of the soul" remains a vista-like process, a perpetually deferred ideal that provides the poet with the power of a god who "walks in noiseless and resistless."

Whitman's poetic power becomes strongest in the last section of the poem. The power is apparent, first of all, in the longest catalogue of the poem, a sixteen-line series of clauses that enacts the transfiguration of ugliness into beauty, sickness into health, evil into good. The catalogue begins with the repetition of the idea of beauty as a permanent characteristic, and the characteristic is presented in the stative line, "The sleepers are very beautiful as they lie unclothed" (161). The image echoes the closing movement of Section 1, where the naked female figures the spiritual union of the many and the one. The poet elaborates upon this theme in the next thirteen lines, and the syntactic parallelism of the catalogue once again mixes the stative and dynamic aspects of the sleepers. For instance, the second line of the catalogue is dynamic, for the static sleepers now begin to "flow hand in hand over the whole earth from east to west as they lie unclothed" (162), but then the dynamic syntax gives way to two lines featuring the "are hand in hand" repetend, which re-establishes the stative aspect of the catalogue. This in turn is transformed into several lines of dynamic syntax, where verbs like "cross," "press," "hold," "shine," "go," "kiss," "salute," "step," "become," "stop," "move," and "open" stress the active, dynamic characteristics of the transfiguration. Of course, these dynamic verbs are counterpointed by several instances of the stative verb "to be": "friend is inarm'd by friend" (168), "the wrong'd is made right" (169), "the call of the slave is one with the master's call" (170), "the suffering of sick persons is relieved" (171), and "the poor distress'd head is free" (172). Four of the five stative clauses occur at the end of lines, and the effect of this formal feature is to stabilize the dynamic action enacted in the first part of the lines.

The perpetually productive character of the oppositions must find some terminus, else the processes of writing and reading would never end. Whit- 
man's strategy for closing the catalogue is to play upon the image of the sleepers:

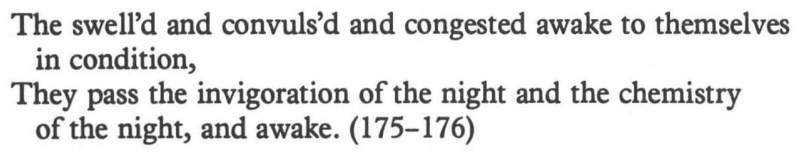

Since there is no formal element to effect the necessary closure, Whitman uses the image of the awaking sleepers, as if the catalogue somehow traversed the span of one night. This technique is similar to the strategy employed in Whitman's longest clausal catalogue, Section 15 of "Song of Myself." In that catalogue, the poet effects closure by developing imagery of sleep, whereas here the imagery is the reverse. But in both cases a temporal transition marks the boundary for the potentially endless series of clauses. ${ }^{14}$

A second point about these last two lines of the catalogue is that the poet once again echoes the "Sleepers" notebook. The "invigoration of the night" recalls Whitman's concern for the "elementary vigor in . . . words" $(D B N$, 3:769). The poet transforms his concern with language into a supposedly objective fact of nature. But this is surely a rhetorical strategy, for Whitman in fact shows that the "vigor" of "chemistry" exists not in the night but in his words, even though he gestures toward the night as the repository of power.

The final stanzas of "The Sleepers" support this contention, for in them the poet returns to a meditation upon himself. The catalogues develop the image of the many and the dynamic transformations of the many through language. Now the poet turns to the one, the "I" which began the poem in complete-though active-confusion:

\section{I too pass from the night,}

I stay a while away $\mathrm{O}$ night, but I return to you again and love you.

Why should I be afraid to trust myself to you?

I am not afraid, I have been well brought forward by you,

I love the rich running day, but I do not desert her in whom I lay so long,

I know not how I came of you and I know not where I go with you, but I know I came well and shall go well.

I will stop only a time with the night, and rise betimes, I will duly pass the day $\mathrm{O}$ my mother, and duly return to you. $(177-184)$

The "I" in this passage is still active, but it now acts coherently, with direction. The poet asserts that he has been "well brought forward" by the night, a phrase clearly adumbrating the theme of spiritual progress, the "efflux of the 
soul." The dynamic poetic self is reflected in the dynamic syntax, and it is especially clear in the closing couplet, where the poet echoes the opening stanza of the poem in order to deny the "stopping" that threatened the "elementary vigor" of his words. Here, the poet enacts a return from the night to the day, and his action thus parallels the awakening of the many sleepers. But that action gives rise to the second return, a return to the night, the mother, the soul. The poem closes in much the same manner as does Section 15 of "Song of Myself," by effecting a figurative return to sleep. But in "The Sleepers," Whitman figures the return as a movement that must inevitably give rise to the countermovement, the passing of the night into day. This figure of the natural cycle of day and night becomes the image of perpetual progress, the infinite process of the "efflux of the soul." Whitman's catalogues do effect a transformation in the speaker of the poem, to be sure, just as they transfigure the many sleepers, restoring them through the "elementary vigor" of Whitman's catalogue rhetoric. But the transformations take place within the temporal frame of perpetual progress, so the ultimate "efflux of the soul" remains both present in the act of the poet's saying and deferred to an always approaching future. In "The Sleepers," then, Whitman exploits the liberty of the "Real Grammar" to show the double aspect of "catching the sign": "Often I catch the sign; and oftener, no doubt, it flies by me as unknown as my neighbor's dreams" $(D B N, 3: 766)$.

\section{Washington and Lee University}

\section{NOTES}

1 The Primer notes appear in Daybooks and Notebooks, ed. William White (New York: New York University Press, 1978), 3:728-757. The present citation appears on p. 735. All references to Whitman's linguistic manuscripts are from this edition and are cited henceforth in my text as " $D B N$, 3."

2 "The 'Real Grammar': Deverbal Style in 'Song of Myself,"” American Literature, 56 (1984), 1-16, and "The Free Growth of Metrical Laws': Syntactic Parallelism in 'Song of Myself,", Style, 18 (1984), 27-42.

In both articles I employ the grammatical distinction between the stative and dynamic aspects of words, which is discussed fully in Randolph Quirk, Sidney Greenbaum, Geoffery Leech, and Jan Svartvik, A Grammar of Contemporary English (New York: Longman Group, 1972), 2.16. The most useful test to determine whether a verb is stative or dynamic, for instance, is to see whether it will form the present progressive tense. If it can, it is dynamic; if it cannot, it is stative. This is because the progressive signifies "an action in progress instead of the occurrence of an action or the existence of a state" (Grammar, 3.39). A verb of inert perception or cognition, for example, cannot take the progressive and is therefore stative: "Do you see what I mean" cannot form "Are you seeing what I am meaning." In Language and the Poet, Marie Borroff points out that the dynamic/stative distinction is conceptual as well as formal: "Broadly speaking, words are called stative or dynamic depending on whether the concepts they signify are regarded as stable or changing, permanent or temporary, absolute or variable" 
(Chicago: University of Chicago Press, 1979), 96. For an interesting recent use of the distinction by a Whitman scholar, see C. Carroll Hollis, Language and Style in "Leaves of Grass" (Baton Rouge: Louisiana State University Press, 1983), 211-232. My essays argue that the dynamic aspect of Whitman's diction and syntax creates a representation of a dynamic poetic self.

3 Whitman: Explorations in Form (Chicago: University of Chicago Press, 1966), 157. Waskow distinguishes between monodrama and dramatic monologue, using the former as a 'convenient rubric for poems in which the focus is an action and the mask that of an 'actor,' a speaker involved at the present time in an action, not describing an action and giving us guides into it, like a narrator, but actually going through the action" (p. 139).

4 "Song of Myself," 1. 716. All quotations from Leaves of Grass refer to Leaves of Grass: A Textual Variorum of the Printed Poems, ed. Sculley Bradley, Harold W. Blodgett, Arthur Golden, William White (New York: New York University Press, 1980). The printed text of the Variorum is the same as the Comprehensive Reader's Edition, ed. Harold Blodgett and Sculley Bradley (New York: New York University Press, 1965).

5 In "'Free Growth"' I provide a taxonomy of Whitman's catalogues based upon the syntactic groups of the phrasal catalogue, the clausal catalogue, and the mixed or phrasal/clausal catalogue. The taxonomy is intended to augment earlier attempts by Gay Wilson Allen, who argued for four types of syntactic parallelism. Allen's argument is set forth in the following: "Biblical Analogies for Walt Whitman's Prosody," Revue anglo-américaine, 10 (1933), 490-507; American Prosody (New York: American Book Co., 1935), 217-243; The New Walt Whitman Handbook (New York: New York University Press, 1975), 207-248. Allen's account has become so generally accepted that it is repeated in the article "Parallelism," Princeton Encyclopedia of Poetry and Poetics, ed. Alex Preminger (Princeton: Princeton University Press, 1974).

For the interpretation of "Song of Myself" as the process of creating a poetic self, see Ivan Marki, The Trial of the Poet: An Interpretation of the First Edition of "Leaves of Grass" (New York: Columbia University Press, 1976), 195-205; John B. Mason, "Walt Whitman's Catalogues: Rhetorical Means for Two Journeys in 'Song of Myself,"' American Literature, 45 (1973), 34-49; and Thomas J. Rountree, "Whitman's Indirect Expression and its Application to 'Song of Myself,'” PMLA, 73 (1958), 549-555.

6 The notebook is part of Container 38 in the Charles E. Feinberg Collection, housed in the Library of Congress Manuscript Division. It is a small, paper-covered notebook containing eleven full leaves and one half-leaf of ruled paper and ruled margins. A similar notebook is the source for much of "Starting from Paumanok," and yet another twelve-leaf notebook contains a few trial lines for "The Sleepers." The "Sleepers" notebook is edited by White in $D B N$, 3:764-770. My quotations from the notebook are taken from this edition, but I have silently omitted the various strike-outs and false starts to present a more coherent transcription of the given passage.

I would like to thank Washington and Lee University for a research grant which enabled me to examine the manuscripts at the Library of Congress and University of Virginia.

$7 D B N, 3: 764$. The phrase "efflux of the soul," as well as much of the imagery ot attraction to strangers, appears in Section 7 of "Song of the Open Road," published in the 1856 edition of Leaves of Grass. It would appear that the first four leaves of the "Sleepers" notebook form trial lines later used in the 1856 poem.

8 Writing about the concept of "Succession" as one of the seven "Lords of Life," for example, Emerson strikes the same tone of mystery: "The secret of the illusoriness is in the necessity of a succession of moods or objects. Gladly we would anchor, but the anchorage is quicksand. This onward trick of nature is too strong for us: Pero si muove. When at night I look at the moon and stars, I seem stationary, and they to hurry. Our love of the real draws us to permanence, but 
health of body consists in circulation, and sanity of mind in variety or facility of association. We need change of objects. Dedication to one thought is quickly odious." The Complete Works of Ralph Waldo Emerson, ed. Edward Waldo Emerson (Boston: Houghton Mifflin, 1903), 3:55. From the passage we might be tempted to infer that Whitman's "love of the real" was more focused upon the human than was Emerson's somewhat impersonal, abstract lyricism.

9 I describe the clausal catalogue of Section 15 in "Free Growth of Metrical Laws," 34-36. My reading of the section emphasizes the mixture of verbs in the simple present tense and verbs in the present progressive tense, a mixture which represents the poetic self and the objective world of occupations as dynamic and temporally performative. Significantly, Section 15 does not divide any of the actions it represents into stanzas; rather, the succession of dynamic lines form one gigantic "stanza," though this is to make the formal term assume proportions nearly monstrous.

10 The phrase "pennants of joy sink flat and lank" appears in "Song of the Open Road," 1.98 The concurrence of the image of "pennants of joy" indicates the close relationship of "Song of the Open Road" to "The Sleepers," for in both poems Whitman is concerned with working through his sexual and spiritual attraction to the many, and in both poems the means of doing so is the dynamic syntax of the catalogue. A thorough comparison of the two poems would seem to be a logical extension of the present project.

$11 D B N, 3: 766$. The "Sleepers" notebook presents several interesting problems in paleography and interpretation. White transcribes the notebook from recto to verso, but the grammar of the quoted passage demands that manuscript leaf [6] follow manuscript leaf [8]. Leaf [6] begins "and bring her naked to his bed," while leaf [6] closes the parenthesis begun on sheet [8]. It is tempting to reverse the order of the third and fourth pages of the notebook, in which case the order of the text would run as follows: [7] (recto), [8] (verso), [5] (recto), [6] (verso). This requires some mental gymnastics on the reader's part. Leaf [7] is a self-contained text, while leaf [8] follows the subject and grammar of leaf [7]. Leaf [5], however, does not follow the grammar of "they undress" which ends leaf [8]; instead, the passage on leaf [5] appears self-contained. Leaf [6] begins in medias res, but the dull pencil stroke matches exactly that of leaf [8], and neither recto bears this type of pencil stroke. We must conclude, then, that regardless of the order of the two pages Whitman wrote verso to verso, from leaf [8] to leaf [6], even though this is not the practice in the rest of the notebook.

Ed Folsom has pointed out to me that leaf [24] of the notebook $(D B N, 3: 770)$ corroborates the ordering of leaves [7], [8], and [6]. The passage on leaf [24] begins with the image of "ten million supple-fingered-wristed gods," which is a revision of leaf [7]; it then develops the image of the poet as "Boss of those gods," a revision of leaf [8]; and it concludes with the image of the poet at the head of the divine "procession," a revision of leaf [6].

Other leaves in the "Sleepers" notebook indicate that Whitman did not always write recto to verso. For instance, the top halves of leaves [14] and [15] bear the same pencil strokes, but the bottom half of [14] is not continuous with the text of the top half. Similarly, leaves [20] and [21] run across the bottom half, from verso to recto. Finally, leaves [21] and [23] seem to be an example of the poet writing from recto to recto.

The jumbled sequence is hardly surprising, and it may account for the fact that the notebook has only recently been identified as connected to "The Sleepers." See R. S. Mishra, "The Sleepers" and Some Whitman Notes," $W W Q R, 1$ (June, 1983), 30-36. I would suggest that the connection is even stronger than Mishra argues; the notebook in fact forms the beginnings of the poem.

12 The lines added to the 1881 version of "Song of Myself" originally appeared in "Starting from Paumanok," the introductory poem to the 1860 edition of Leaves of Grass. See Variorum, 2:275.

13 The passage was dropped in the 1881 edition of Leaves, when Whitman arranged and revised the poems for the final time. Early draft lines of the passage appear in the twelve-sheet 
notebook mentioned above. See $D B N, 3: 763$. The Barrett Collection at the University of Virginia also contains manuscript drafts of the section, though they have been mistakenly bound in a volume containing the manuscript drafts of "Song of Myself."

14 For an account of this method of closure, see Barbara Herrnstein Smith, Poetic Closure: $A$ Study of How Poems End (Chicago: University of Chicago Press, 1968), 172-182. 